\title{
1 Developing Fruit-based Nutritious Snack Bars
}

2 Edson P. Silva ${ }^{1,2}$; Heloisa H. Siqueira ${ }^{1}$; Rafael Carvalho do Lago ${ }^{1}$; Cristina M. Rosell ${ }^{2 *}$,

3 Eduardo V. de Barros Vilas Boas ${ }^{1}$

$4 \quad{ }^{1}$ Federal University of Lavras, Food Science Department, 3037, Cep 37200-000 Lavras.

5 Minas Gerais. Brazil.

$6{ }^{2}$ Institute of Agrochemistry and Food Technology. CSIC. Avenida Agustin Escardino, 7 7. Paterna 46980. Valencia. Spain.

$8 \quad$ Address for correspondence: * crosell@iata.csic.es

$9 \quad$ Running Title: Marolo flour for nutritious snacks bars

Abstract

BACKGROUND: Marolo (Annona crassiflora Mart) is a typical Savannah fruit very nutritious and highly appreciated. However, its consumption has been limited to fresh fruit. The objective of this study was to evaluate the potential use of marolo flour in the production of healthy snack bars to valorize this fruit and to provide an alternative ready to eat nutritious product. Snack bars containing increasing amounts of marolo flour $(5 \mathrm{~g} / 100 \mathrm{~g}, 10 \mathrm{~g} / 100 \mathrm{~g}, 15 \mathrm{~g} / 100 \mathrm{~g}, 20 \mathrm{~g} / 100 \mathrm{~g}$, expressed in $\mathrm{w} / \mathrm{w})$ were produced and the physico-chemical and sensory characteristics were determined. RESULTS: Levels up to $20 \%$ marolo flour can be incorporated in snack bars with some minor changes in $\mathrm{pH}$ and moisture content but with an increase of 2.4 fold in dietary fiber content and also 1.3 fold of vitamin $\mathrm{C}$, minerals and antioxidant activity. In addition, up to $10 \%$ marolo flour improves significantly the sensory properties of the snack bars, namely appearance, taste, texture and overall acceptance. CONCLUSION: Marolo flour can be considered alternative flour for obtaining healthy snack bars, with increased nutritional and sensory quality. 
Key words: Snack bars, fruit flour, nutrient composition, sensory analysis.

\section{INTRODUCTION}

28

The demands for nutritious and safe foods is growing worldwide, since eating a balanced diet is the recommended way to prevent or correct health problem as obesity, diabetes, malnutrition, heart disease, among other ailments that largely have their origin in dietary errors. The new trend for consumption of healthy, innovative and convenience food is driven the market of cereal-bars to a gradual growth. The change in the lifestyle of consumers and their health awareness have made that scientists and food industries change formulations and ingredients for increasing food nutritional value and safety. Cereal-bars are very versatile product, made of processed cereals mixed with a variety of ingredients, which selection depends on the targeted population group. ${ }^{1}$ In fact, wheat-soy snack bars have designed as nutritional bars for providing the necessary nutrients for feeding people on-the-go ${ }^{2}$, and the use of walnuts have been successfully used in the production of snack bars with a significant amount of crude fiber and lipids ${ }^{3}$; or even high-protein snack bars have been produced for consumers engaged in sports and dieting ${ }^{4}$. The ingredients must be combined appropriately to ensure that they complement each other in the characteristics of flavor, texture and physical properties ${ }^{5}$. Therefore, snack bars are convenient products addressed to healthy people, but also they constitute a compact product to provide energy and micronutrients to people in famine suffering areas of the world.

In some countries the consumption of snack bars is very popular and continuously increasing, which prompted the food industries to invest in new cereal-bar formulations and ingredients. According to Euromonitor International ${ }^{6}$, the growth forecast of energy and nutrition snack bars from 2009 to 2014 will be around 33\%

The Savanna is an important Brazilian eco-system with a large number of fruit species. 
51 In spite of many fruits are edible, rich in pigments and have distinctive aromas, their

52 consumption has been limited to local populations. The marolo or araticum (Annona crassiflora Mart) is a typical fruit of Cerrados, Cerradoes, Cerrado denso and Campo

Cerrado drain rock that belongs to the Annonaceae family. The fruit tree grows in the states of Bahia, Distrito Federal, Goias, Maranhao, Mato Grosso, Mato Grosso do Sul, Minas Gerais, Pará, Sao Paulo and Tocantins. ${ }^{7}$ Marolo has recently attract attention due to its sensory characteristics such as color, aroma and flavour, besides nutritional qualities like high levels of B-complex vitamins, such as thiamine $(0.04 \mathrm{mg} / 100 \mathrm{~g})$ and riboflavin $(0.07 \mathrm{mg} / 100 \mathrm{~g})$, in addition to levels of ascorbic acid $(37.5 \mathrm{mg} / 100 \mathrm{~g})$, total phenolics $(0.5 \mathrm{~g} / 100 \mathrm{~g})$, crude fiber $(4.5 \mathrm{~g} / 100 \mathrm{~g})$, beta carotene $(50 \mathrm{mg} / 100 \mathrm{~g})$ and carotenoids $(5.9 \mu \mathrm{g} / \mathrm{g}) .{ }^{8}$ Canniatti-Brazaca ${ }^{9}$ explained the interest in Marolo by its content in polyphenols (flavonoids and isoflavones) oligosaccharides (such as fructoligosaccharides), carotenoids and ascorbic acid. Despite their health-promoting compounds, only the native people consume marolo as fresh fruit or frozen, the former is used to prepare juices, ice-creams, jellies, and jams. Their limited consumption is partly due to the scarce information regarding potential uses, processing and quality of processed foods obtained from marolo. Recently, Corrêa et al. ${ }^{10}$ evaluated the physicochemical properties of fresh and dehydrated marolo obtained by freeze-drying or convective hot-air drying. They found that dehydrated products could be a source of alimentary fiber and some fatty acids, providing a new alternative for extending the applicability of this fruit.

The objective of this study was to evaluate the potential use of marolo flour in the production of healthy snack bars to valorize this fruit and to provide an alternative ready to eat nutritious product. 
77 Fruits of marolo (Annona crassiflora Mart) were harvested in the area of Cerrado native on the South of Minas Gerais State. Ingredients were purchased in local market. Reagents were of analytical grade.

\section{Preparation of marolo flour}

Fruits were washed and sanitized using a solution of $1.216 \mu \mathrm{M}$ sodium hypochlorite for the removal of field dirt and impurities. Pulp was separated from the seed by using a depulper Hauber Macanuda (model MJI-05, series 074-09 Joinvile-SC- Brazil). Pulps, which had jelly structure, were dehydrated at $65^{\circ} \mathrm{C}$ for $48 \mathrm{~h}$ in a laboratory oven and then ground in industrial blender using a common sieve mash 3 for obtaining the flour. Final moisture content of the flour was $9.5 \%$.

\section{Processing of snack bars}

The snack bars production was carried out in the Department of Food Science of the University Federal of Lavras - Brazil. The process technology used in the formulation of food bars was reported by Torres ${ }^{11}$, with some modifications. The snack bar recipes consisted in $400 \mathrm{~g} \mathrm{~kg}^{-1}$ crashed corn starch biscuit, $60 \mathrm{~g} \mathrm{~kg}^{-1}$ oat flakes, $60 \mathrm{~g} \mathrm{~kg}^{-1}$ skimmed milk powder, $40 \mathrm{~g} \mathrm{~kg}^{-1}$ rice flakes, $450 \mathrm{~g} \mathrm{~kg}^{-1}$ of corn syrup. When present, crashed corn starch biscuit was replaced by increasing amounts of marolo flour $(5 \%$, $10 \% 15 \%$ and $20 \%$, expressed in $\mathrm{w} / \mathrm{w})$.

Dry ingredients (corn starch biscuit, skimmed milk powder, rice flakes, oat flakes) were mixed using a blender. Simultaneously, binding syrup was prepared by mixing corn glucose without applying heat. Syrup was added to solids blend and mixed till obtaining a uniform mixture, which was then manually laminated, left to stand for 8 hours and 
101

then cut $(10 \times 2 \mathrm{~cm}$, approximately $25 \mathrm{~g}$ each), packed in aluminum-coated cellophane and kept at $20^{\circ} \mathrm{C}$ until further analysis.

\section{Physico-Chemical analysis}

The water activity (Aw) of the bars was measured in AQUA Labmodel 3TE Series 3B v 3.0 (Decagon Devices Inc. Washington, USA). Five grams of bars were homogenized with $45 \mathrm{ml}$ of distilled water in a Tecnal Turratec TE-102 (Piracicaba, Sao Paulo, Brazil) at $22,000 \mathrm{rpm}$ for $1 \mathrm{~min}$ at $20^{\circ} \mathrm{C}$. Then, sample was poured over a screen filter, and the filtrate was used for further analysis. The $\mathrm{pH}$ was directly measured on the filtrate with a pHmeter Schott Handylab (London, UK), following the AOAC method. ${ }^{12}$ The water soluble compounds (SS) were also quantified in the filtrate by refraction index using a digital refractometer Reichert AR 200 (Tokyo, Japan), with automatic temperature adjustment and the results were expressed in Brix degree, as described in AOAC method. ${ }^{12}$

The chemical composition (moisture, lipids, proteins, crude fiber and ash) of snack bars was determined according to AOAC corresponding standard methods. ${ }^{13}$ Total carbohydrates were determinate by difference subtracting $100 \mathrm{~g}$ minus the sum of protein, ash and fat expressed in $\mathrm{g} \mathrm{kg}^{-1}$. Minerals (calcium, phosphorous, iron, potassium) were quantified following AOAC methods. ${ }^{12}$ The total dietary fiber, soluble and insoluble fibers were determined by enzymatic-gravimetric method ${ }^{13}$, using the total dietary fiber assay kit (Sigma-Aldrich, St. Louis, MO, USA). The vitamin C was determined of colorimetric method used 2,4-dinitrophenylhydrazine following the method described by Strohecker et al. ${ }^{14}$ The absorbance was measured at $520 \mathrm{~nm}$ in a Beckman 640B spectrophotometer and the results expressed in $\mathrm{mg} \mathrm{kg}^{-1}$ of ascorbic 
acidity. The antioxidant activity was estimated with the stable free radical 2,2-diphenyl1-picryl hydrazyl (DPPH). ${ }^{15,16}$

\section{Sensory analysis}

Hedonic sensory evaluation of snack bars was conducted with 100 usual consumer volunteers of those products. Consumer test was carried out in the Sensory Analysis Laboratory of the Department of Food Science of University Federal of Lavras (Brasil) in individual booths. Snack bars were evaluated for appearance, aroma, taste, texture and overall acceptability on a nine-point hedonic scale. ${ }^{17}$ Attributes were scored on a scale varying from "9 = like extremely" to " $1=$ dislike extremely". Samples were presented in white plastic dishes coded with three-digit random numbers and served in a randomized order.

\section{Statistical Analysis}

The results were expressed as mean values \pm standard deviation. Data were analyzed using one-way analysis of variance (ANOVA) to determine whether there was significant difference between snack bars by using Statgraphics Plus V 7.1 program (Statistical Graphics Corporation, UK). Fisher's least significant differences (LSD) test was used to differentiate means with $95 \%$ confidence.

\section{RESULTS AND DISCUSSION}

Physico-chemical characteristics of the marolo flour were determined. The proximate composition was $29.2 \mathrm{~g} \mathrm{~kg}^{-1}$ protein, $48.3 \mathrm{~g} \mathrm{~kg}^{-1}$ of lipid and $174.3 \mathrm{~g} \mathrm{~kg}^{-1}$ dietary fiber, besides $1830.6 \mathrm{mg} \mathrm{kg}^{-1}$ vitamin $\mathrm{C}, 34.33 \mathrm{mg} \mathrm{kg}^{-1} \mathrm{Fe}$ and $1700 \mathrm{mg} \mathrm{kg}^{-1} \mathrm{Ca}$ and $48.76^{\circ}$ Brix. 
Physical and chemical characteristics of the snack bars obtained with increasing levels

151 of marolo flour were determined. Marolo fruit flour has acid $\mathrm{pH}$ (4.96), which could affect the snack bars, because of that, the final $\mathrm{pH}$ of the supplemented snack bars was determined (Table 1). The presence of marolo flour in snack bars resulted in a significant $(P<0.05) \mathrm{pH}$ decrease. Taking into account that freeze-dried flour from marolo has $\mathrm{pH} 5.34^{10}$, that can explain the $\mathrm{pH}$ results. The decrease of $\mathrm{pH}$ induced by the marolo flour was rather similar to the one produced by cupuassu (Theobroma grandiflorum) peel flour (0.24 units of $\mathrm{pH})$, another fruit tree from Brazilian Amazon, when added up to $9 \%$ in a whole bread formulation. ${ }^{18}$ Aramouni et al. ${ }^{2}$ prepared different wheat and soy-based bars with $\mathrm{pH}$ ranging from 5.11 to 6.45 , which was mainly explained by the $\mathrm{pH}$ of the wheat or soybean flours. with the presence of up $10 \%$ marolo flour, since cornstarch biscuit, utilized as solid base of snack bars, was replaced with marolo flour. Water activity of the snack bars (0.56) was not influenced by the presence of marolo flour, thus it is expected that mechanical properties, stability and shelf life would not be altered. Value of water activity agrees with previous results for cereal and nut bars. ${ }^{3}$ Low water activity values are desirable to ensure low risk of microbial proliferation and pathogenic spoilage and with the highest level of fruit flour tested (20\%).

The proximate composition (Table 2$)$ of snack bar was significantly $(P<0.05)$ affected with the addition of marolo flour. The fat content increased from $21.2 \mathrm{~g} \mathrm{~kg}^{-1}$ to $26.0 \mathrm{~g}$ $\mathrm{kg}^{-1}$ when enhancing marolo flour addition. An increase in the fat content was expected 
175 due to the lipid content of marolo flour $\left(48.3 \mathrm{~g} \mathrm{~kg}^{-1}\right)^{10}$, that tendency has been also 176 observed in other fruits from Brazilian Amazon, for instance when added up to 9\% 177 cupuassu peel flour in a whole bread formulation. ${ }^{18}$ Taking into account that this type of snack bars are categorized as energy and nutrition bars, the increase observed in the fat content would be foreseen as positive effect. Mineral content of marolo supplemented snack bars was within values encountered for cereal and nut bars $(1.5-2.1 \%){ }^{3}$ However, the most important contribution of marolo flour to snack bars was in fiber content and in proteins. The crude fiber content of the snack bars showed a $45 \%$ increase with the addition of $20 \%$ marolo flour, and regarding the proteins, 1.2 fold enhancement was observed compared to the control bars. The protein values of the marolo supplemented snack bars were higher than the values found by Sun-Waterhouse et al. ${ }^{20}$ when compared the composition of fruit-based functional snack bars, which ranged from 10.7 (71.9-115.9 $\left.\mathrm{g} \mathrm{kg}^{-1}\right)^{3}$, and for wheat and soy snack bars $\left(75-175 \mathrm{~g} \mathrm{~kg}^{-1}\right)^{2}$, but lower in snack bars enriched with soybean texturized protein and camu-camu $\left(15.4 \mathrm{~g} \mathrm{~kg}^{-1}\right){ }^{21}$ Lin et al. $^{22}$ studying the factors influencing dietary protein sources stated that proteins can have very positive effect in the organism human, contributing with the control of the pressure blood and the effect was dependent on the type of protein.

Total dietary fiber (TDF) of supplemented snack bars ranged from $46.5 \mathrm{~g} \mathrm{~kg}^{-1}$ to $64.6 \mathrm{~g}$ $\mathrm{kg}^{-1}$, which was significantly higher than the TDF of the snack bar without marolo flour (control) (27.1 $\left.\mathrm{g} \mathrm{kg}^{-1}\right)$, thus all supplemented snack bars contained good amount of dietary fiber $\left(>30 \mathrm{~g} \mathrm{~kg}^{-1}\right)$ (Table 3). Supplemented snack bars showed higher amount of insoluble dietary fiber than soluble dietary fraction, the former barely present in this bars. Therefore, snack bars supplemented with up to $15 \%$ marolo flour can be labeled as source of fiber according to Brazilian legislation that establishes for solid food to be 
considered "source of fiber" it should present at least $3 \mathrm{~g}$ of fiber for each $100 \mathrm{~g}$ of food; whereas bars supplemented with $20 \%$ marolo flour might be labeled as "high fiber content", since it presented more than $6 \mathrm{~g}$ of fiber for each $100 \mathrm{~g}$ food. ${ }^{23}$ Therefore, this result confirmed previous suggestion of Corrêa et al. ${ }^{10}$ regarding that dehydrated marolo products would be potential sources of fibers in food preparations. The positive role of fiber in health and disease prevention, particularly in digestive health, energy balance, and cancer, heart and diabetes problems justify the demand of increasing fiber dietary content in the daily diet. $^{24}$

The micronutrients are necessary compounds for an appropriate physiological state of the body that can be administered orally in the diet, enteral or parenteral, being necessary to keep an adequate balance. ${ }^{24,25}$ Mineral elements must be supplied from food because they cannot be synthetized, and considering the worldwide deficiencies in different minerals, it is worthy to provide convenient foods with enough amounts of minerals. ${ }^{26}$ The supplemented snack bars contained significantly higher amounts of nitrogen, phosphorous, potassium, manganese, zinc and iron than the control bar (Table 4). Calcium and magnesium content were significantly increased when snack bars were supplemented with at least $10 \%$ or $15 \%$ marolo flour, respectively. The contribution of the marolo flour to the cupper content was only significantly increased when $15 \%$ marolo flour was present. In general, the mineral content in the supplemented snack bars increased with enhancing the levels of marolo flour. Damiani et al. ${ }^{27}$, when characterizing Savannah fruits, found the following mineral contents in fresh marolo pulp: $1920 \mathrm{mg} \mathrm{kg}^{-1}$ calcium, $350 \mathrm{mg} \mathrm{kg}^{-1}$, magnesium, $3.45 \mathrm{mg} \mathrm{kg}^{-1}$ of zinc, $3.82 \mathrm{mg} \mathrm{kg}^{-}$ ${ }^{1}$ of iron, $2.2 \mathrm{mg} \mathrm{kg}^{-1}$ of cooper and $220 \mathrm{mg} \mathrm{kg}^{-1}$ phosphorus. Considering the high mineral content of the fresh fruits, it was really expected such high contribution in the micronutrient content of the supplemented snack bars. ${ }^{28}$ 
225 Marolo fruit is an important source of vitamin $\mathrm{C}\left(9,500 \mathrm{~g} \mathrm{~kg}^{-1}\right)$, thus it could be expected a significant contribution of this vitamin when marolo flour was added to the

227 bars. When adding increasing levels of marolo flour to snack bars, a progressive increase of vitamin $\mathrm{C}$ was observed, although that increase was only significant when marolo flour level was higher than $10 \%$ (Table 3 ). It is noteworthy to stress that by supplementing 20\% marolo flour, vitamin C content of the snack bars was $33 \%$ higher than the value obtained in the control bars. Antioxidant effects of vitamin $\mathrm{C}$ have been demonstrated in many experiments in vitro; and it is also known the oxidants role in different human diseases such as atherosclerosis and cancer. ${ }^{28}$ Although, the direct relationship between protective or prevention effects of vitamin $\mathrm{C}$ and disease incidence has not been demonstrated, optimal dosing is critical to intervention studies where food sources of vitamin $\mathrm{C}$ are required.

237 Bearing in mind that marolo fruit is rich in antioxidant compounds (342.9 units $\mathrm{L}^{-1}$ of total antioxidant potential) ${ }^{27}$, foods supplemented with its dehydrated products might be also suppliers of those compounds. In Table 3 is shown that marolo flour addition in increasing levels to snack bars formulation resulted in a progressive rising of DPPH radical-scavenging activities that in the case of $20 \%$ supplemented bars was more than three-fold higher as compared to the control. There is scarce information about the level of antioxidant activities in similar products. Nevertheless, blends of extruded rice and Cannabis sativa L. (known as hemp) (60:40) could increase by two-fold the DPPH radical-scavenging activity of the energy bars made of extruded rice. ${ }^{30}$

247 Considering its nutritional value, marolo flour is certainly a desirable ingredient in a convenience product such snack bars, but a sensory test is decisive for testing its acceptance. Snack bars supplemented with up to $20 \%$ marolo flour showed all the 
scores significantly above the predetermined acceptability level $(5=$ no like, no dislike $)$

251 (Table 5). Mean value score for the sensory descriptors (appearance, aroma, taste,

252

253

254

255

256

257

258

259

260

261

262

263

264

265

266

267

268

269

270 texture, overall acceptance) was 7 (comparable to "liked moderately" on the 9-point hedonic scale) slightly superior to the control bar. 5\% supplemented bars received the highest score for appearance, taste, texture and overall acceptance, whereas aroma was scored higher at the maximum supplementation tested (20\%). Therefore, marolo flour added up to $10 \%$ to snack bars improved significantly the sensory perception of that product, and superior levels (up to $20 \%$ supplementation) gave snack bars with appearance and taste similar to those of the control, besides lower overall acceptance and better aroma and texture than the control. Sensory properties of the supplemented snack bars confirm the great potential of marolo flour as ingredient for this type of products, since its own sensory characteristics such as color, aroma and flavour are greatly appreciated.

\section{CONCLUSIONS}

The incorporation of marolo flour in a new product as snack bar is feasible and it could be considered as a new highly nutritional ingredient for the food industry, which can also provide a new taste for consumers. Levels up to $20 \%$ marolo flour can be effectively incorporated in snack bars, considering the overall results in physicochemical properties and sensory perception of those products. Incorporation of levels of marolo flour of up to $20 \%$ in snack bars provides a food product with substantial improvement in dietary fiber content and also vitamin $\mathrm{C}$, minerals and antioxidant activity. Besides the beneficial nutritional effects, the addition of up to $10 \%$ marolo flour improves significantly the sensory properties of the snack bars. 
275 Authors acknowledge the financial support of CAPES; FAPEMIG, CNPq, Spanish 276 Scientific Research Council (CSIC) and the Generalitat Valenciana (Project Prometeo 277 2012/064). EP da Silva would like to thank predoctoral grant by the University of 278 Lavras (Lavras, Brazil).

279

\section{REFERENCES}

281

[1] Bower JA, and Whitten R, Sensory characteristics and consumer linking for cereal 282 bar snack foods. J Sensory Studies 15: 327-345 (2000).

283

[2] Aramouni FM, and Abu-Ghoush MH, Physicochemical and sensory characteristics of no-bake wheat-soy snack bars. J Sci Food Agric 91: 44-51 (2011).

[3] Estévez AM, Escobar B, Vásquez M, Castillo E, Araya E, and Zacarías I, Cereal and nut bars, nutritional quality and storage stability. Plant Foods Hum Nutr 47: 309-317 (1995).

288

[4] Hogan AS, Chaurin V, O'Kennedy BT, and Kelly PM, Influence of dairy proteins on textural changes in high-protein bars. Int Dairy J 26: 58-65 (2012).

[5] Izzo M, and Niness K, Formulating Nutrition Bars with Inulin and Oligofructose.

291 Cereal Foods World 46: 102-105 (2001).

292

[6] Euromonitor International, http://www.euromonitor.com/snack-bars (last accessed

293 May 2013).

294

[7] Almeida SP, Frutas nativas do cerrado: caracterização físico-química e fonte potencial de nutrientes. Cerrado: ambiente e flora. Planaltina, DF: Embrapa-CPAC, p.247-281 (1998)

[8] Agostini TS, Cecchi HM, and Godoy HT, Carotenóides no marolo in natura e em produtos preparo caseiro. Ciencia Tecnol Alimentos 16: 67-71 (1996). 
[9] Canniatti-Brazaca SG, Pós-colheita de frutas e hortaliças. Visão Agrícola, Piracicaba

[10] Corrêa SC, Clerici MTPS, Garcia JS, Ferreira EB, Eberlin MN, and Azevedo L

Evaluation of dehydrated marolo (Annona crassiflora) flour and carpels by freezedrying and convective hot-air drying. Food Res Int 44: 2385-2390 (2011).

[11] Torres ER, Desenvolvimento de barra de cereais formuladas com ingredientes regionais. Dissertação (mestrado em Engenharia de Processos) - Universidade Tiradentes. Aracaju, 78p.:Il.2009 (2009).

307

[12] AOAC, Official methods of Analysis, Washington, DC: Association of Official Analytical Chemists (1998).

[13] AACC, International Approved Methods, 11th edn. St Paul, MN: American Association of Cereal Chemists International (2000).

[14] Strohecker RL, and Henning HM, Análisis de vitaminas: métodos comprobados. Madrid: Paz Montalvo, 428p. (1967)

[15] Rufino MS, Do M, Alves RE, Morais SM, De Sampaio CG, Perez-Jimenez J, and

Saura-Calixto FD, Metodologia científica: determinação da atividade antioxidante total em frutas pela captura do radical livre DPPH. Fortaleza: Embrapa,’Não paginado". Comunicado técnico (2007).

[16] Roesler R, Malta LG, Carrasco LC, Holanda RB, Souza CAS, and Pastore GM Antioxidante de frutas do cerrado. Ciência Tecnol Alimentos 27: 53-60 (2007). [17] Meilgaard M, Civille GV, and Carr BT, Sensory evaluation techniques; $2^{\text {nd }}$ ed. 320 Florida: CRC Press 1991; p.354.

[18] Salgado JM, Rodrigues BS, Donado-Pestana CM, Dias CTS, and Morzelle MC, 
323 phytochemicals in whole-bread preparations. Plant Foods Hum Nutr 66: 384-390 324 (2011).

325 [19] Siroh D, Sievert B, Desjardins J, and Geoffroy G, Food Bar. Patent Application No 838510/09. Publication number 20020039608US-A1 (2002). [20] Sun-Waterhouse D, Teoh A, Massarotto C, Wibisono R, and Wadwa S, 328 Comparative analysis of fruit-based functional snack bars. Food Chem 119: 1369-1379 329 (2010).

[21] Peuckert YP, Vieira VB, Hecktheuer LHR, Marques CT, and Rosa CS, Caracterizaçao e aceitabilidade de barras de cereais adicionadas de proteína texturizada de soja e camu-camu (Myrciaria dúbia) Alim Nutr Araraquara 21: 147-152 (2010). [22] Lin PH, Miwa S, Li YJ, Wang Y, Levy E, Lastor K, and Champagne C, Factors influencing dietary protein sources in the premier trial population. J Am Diet Assoc 110: 291-295 (2010).

[23] Brasil, Agencia Nacional de Vigilancia Sanitaria. Portaria ${ }^{\mathrm{o}} 27$ de 13 de Janeiro de 1998. Regulamento técnico sobre a informação nutricional complementar. Available in http://www.anvisa.gov.br>acesso (last access 10th Apr 2012).

[24] Champ M, Langkilde AM, Brouns F, Kettlitz B, Collet Y, and Le B, Advances in dietary fiber characterization. 1. Definition of dietary fiber, physiological relevance, health benefits and analytical aspects. Nutr Res Rev 16: 71-82 (2003). [25] Davidi A, Reynolds J, Njike VY, Ma Y, Doughty K, and Katz DL, The effect of 343 the addition of daily fruit and nut bars to diet on weight, and cardiac risk profile, in 344 overweight adults. J Human Nutr Diet 24: 543-551 (2011). [26] Rosell CM, Vitamin and mineral fortification of bread". In: Technology of 346 Functional Cereal Products. Ed B. Hamaker. Woodhead Publishing Ltd, Cambridge, UK. Pp 336-361 (2007). 
348 [27] Damiani C, Vilas Boas E, Asqueri ER, Lage ME, Oliveira RA, Silva FA, Pinto

349 DM, Rodrigues LJ, Silva EP, and Paula N, Characterization of fruits from the savanna:

350 Araça (Psidium guinnensis Sw) and Marolo (Annona crassiflora Mart). Food Sci

351 Technol 31: 723-729(2011).

352 [28] Carvalho MG, Costa JMC, Rodrigues MCP, Sousa PHM, and Clemente E, 353 Formulation and sensory acceptance of cereal-bars made with almonds of chichá, 354 sapucaia and gurguéia nuts. Food Sci J 5: 26-30 (2011).

355 [29] Padayatty SJ, Katz A, Wang Y, Eck P, Kwon O, Lee JH, Chen S, Corpe C, Dutta 356 A, Dutta SK, and Levine M, Vitamin C as an antioxidant: evaluation of its role in 357 disease prevention. J Am Coll Nutr 22: 18-35 (2003).

358 [30] Norajit K, Gu BJ, and Ryu GH, Effects of the addition of hemp powder on the 359 physicochemical properties and energy bar qualities of extruded rice. Food Chem 129: 360 1919-1925 (2011). 
Table 1. Physico-chemical characteristics of the snack bars supplemented with marolo

365 flour (SSB).

\begin{tabular}{lcccc} 
Samples & pH & SS $\left({ }^{\mathbf{o}} \mathbf{B r i x}\right)$ & Aw & $\begin{array}{c}\text { Moisture content } \\
\left.\mathbf{( g ~ k g}^{-1}\right)\end{array}$ \\
\hline Control & $6.92 \pm 0.01^{\mathrm{c}}$ & $85.44 \pm 0.33^{\mathrm{c}}$ & $0.56 \pm 0.01$ & $91.4 \pm 0.16^{\mathrm{b}}$ \\
SSB 5\% & $6.85 \pm 0.01^{\mathrm{a}}$ & $60.23 \pm 1.65^{\mathrm{b}}$ & $0.56 \pm 0.01$ & $91.2 \pm 0.05^{\mathrm{b}}$ \\
SSB 10\% & $6.89 \pm 0.01^{\mathrm{b}}$ & $54.51 \pm 1.76^{\mathrm{a}}$ & $0.56 \pm 0.01$ & $90.9 \pm 0.03^{\mathrm{b}}$ \\
SSB 15\% & $6.88 \pm 0.02^{\mathrm{b}}$ & $54.38 \pm 1.38^{\mathrm{a}}$ & $0.56 \pm 0.01$ & $90.9 \pm 0.03^{\mathrm{b}}$ \\
SSB 20\% & $6.84 \pm 0.02^{\mathrm{a}}$ & $54.29 \pm 1.20^{\mathrm{a}}$ & $0.56 \pm 0.01$ & $84.7 \pm 0.47^{\mathrm{a}}$ \\
\hline
\end{tabular}

Values followed by different letters within columns indicate significant differences $(P \leq 0.05)$. Fisher's least significant differences (LSD) test was used to differentiate means with $95 \%$ confidence.

Table 2. Proximate composition $\left(\mathrm{g} \mathrm{kg}^{-1}\right.$, as is) of snack bars supplemented with

different concentrations of marolo flour (SSB).

\begin{tabular}{llllll} 
Samples & Fat & Crude Fiber & Proteins & Ash & Carbohydrates \\
\hline Control & $21.2 \pm 0.2^{\mathrm{ab}}$ & $27.6 \pm 2.8^{\mathrm{a}}$ & $61.2 \pm 3.1^{\mathrm{a}}$ & $18.3 \pm 0.1^{\mathrm{b}}$ & $807.9 \pm 9.8^{\mathrm{c}}$ \\
SSB 5\% & $24.0 \pm 2.4^{\mathrm{b}}$ & $33.8 \pm 1.6^{\mathrm{b}}$ & $69.3 \pm 3.1^{\mathrm{b}}$ & $19.1 \pm 0.1^{\mathrm{b}}$ & $796.4 \pm 3.7^{\mathrm{b}}$ \\
SSB 10\% & $24.0 \pm 0.3^{\mathrm{b}}$ & $33.9 \pm 0.2^{\mathrm{b}}$ & $69.3 \pm 1.9^{\mathrm{b}}$ & $15.9 \pm 0.5^{\mathrm{a}}$ & $799.9 \pm 17.2^{\mathrm{b}}$ \\
SSB 15\% & $26.0 \pm 1.9^{\mathrm{c}}$ & $34.6 \pm 2.1^{\mathrm{c}}$ & $72.5 \pm 1.4^{\mathrm{c}}$ & $15.1 \pm 3.8^{\mathrm{a}}$ & $795.5 \pm 13.3^{\mathrm{ab}}$ \\
SSB 20\% & $26.0 \pm 0.6^{\mathrm{c}}$ & $40.0 \pm 2.2^{\mathrm{d}}$ & $72.5 \pm 1.8^{\mathrm{c}}$ & $19.5 \pm 1.6^{\mathrm{b}}$ & $797.3 \pm 7.3^{\mathrm{a}}$
\end{tabular}
confidence. 
379 Table 3. Dietary fiber composition, vitamin $\mathrm{C}$ and antioxidant activity of marolo flour supplemented snack bars (SSB).

\begin{tabular}{|c|c|c|c|c|c|}
\hline Samples & IDF $\left(\mathrm{g} \mathrm{kg}^{-1}\right)$ & SDF $\left(\mathrm{g} \mathrm{kg}^{-1}\right)$ & TDF $\left(\mathrm{g} \mathrm{kg}^{-1}\right)$ & $\begin{array}{c}\text { Vitamin C } \\
\left(\mathrm{mg} \mathrm{kg}^{-1}\right)\end{array}$ & $\mathbf{A P}$ \\
\hline Control & $27.0 \pm 3.7^{\mathrm{a}}$ & $0.02 \pm 0.01^{\mathrm{a}}$ & $27.1 \pm 3.5^{\mathrm{a}}$ & $298.7 \pm 12.0^{\mathrm{a}}$ & $51.3 \pm 2.0^{\mathrm{a}}$ \\
\hline SSB 5\% & $46.4 \pm 0.6^{\mathrm{b}}$ & $0.02 \pm 0.02^{\mathrm{a}}$ & $46.5 \pm 0.6^{\mathrm{b}}$ & $304.3 \pm 9.5^{\mathrm{ab}}$ & $78.6 \pm 4.0^{\mathrm{b}}$ \\
\hline SSB 10\% & $47.5 \pm 1.2^{b}$ & $0.05 \pm 0.01^{b}$ & $47.6 \pm 1.3^{b}$ & $317.6 \pm 35.0^{\mathrm{ab}}$ & $76.3 \pm 3.5^{\mathrm{b}}$ \\
\hline SSB $15 \%$ & $53.5 \pm 2.3^{\mathrm{c}}$ & $0.07 \pm 0.01^{\mathrm{c}}$ & $53.7 \pm 2.2^{\mathrm{c}}$ & $338.7 \pm 15.0^{\mathrm{b}}$ & $89.1 \pm 12.3^{\mathrm{b}}$ \\
\hline SSB 20\% & $64.5 \pm 0.6^{\mathrm{d}}$ & $0.09 \pm 0.01^{\mathrm{d}}$ & $64.6 \pm 0.6^{\mathrm{d}}$ & $395.9 \pm 11.5^{\mathrm{c}}$ & $163.0 \pm 18.7^{\mathrm{c}}$ \\
\hline \multicolumn{6}{|c|}{$\begin{array}{l}\text { Values followed by different letters within columns indicate significant differences }(P \leq 0.05) \text {. } \\
\text { TDF: total dietary fiber; IDF: insoluble dietary fiber; SDF: soluble dietary fiber. AP: antioxidant } \\
\text { potential expressed as the discoloration of the DPPH radical } \mathrm{L}^{-1} \text {. }\end{array}$} \\
\hline
\end{tabular}


Table 4. Mineral content of supplemented snack bars (SSB) with marolo flour addition.

\begin{tabular}{|c|c|c|c|c|c|c|c|c|c|}
\hline & \multicolumn{5}{|c|}{$\begin{array}{l}\text { Minerals } \\
\left(\mathrm{mg} \mathrm{kg}^{-1}\right)\end{array}$} & \multicolumn{4}{|c|}{$\left(\mathrm{mg} \mathrm{kg}^{-1}\right)$} \\
\hline & $\mathbf{N}$ & $\mathbf{P}$ & $\mathbf{K}$ & $\mathbf{C a}$ & Mg & $\mathrm{Cu}$ & Mn & Zn & $\mathbf{F e}$ \\
\hline \multicolumn{10}{|l|}{ Samples } \\
\hline Control & $9,800 \pm 200^{\mathrm{a}}$ & $1,400 \pm 100^{\mathrm{a}}$ & $1,800 \pm 200^{\mathrm{a}}$ & $7,000 \pm 300^{\mathrm{a}}$ & $200 \pm 10^{\mathrm{a}}$ & $1.07 \pm 0.01^{\mathrm{a}}$ & $3.56 \pm 0.01^{\mathrm{a}}$ & $13.78 \pm 0.02^{\mathrm{a}}$ & $24.27 \pm 0.01^{\mathrm{a}}$ \\
\hline SSB 5\% & $11,100 \pm 300^{\mathrm{b}}$ & $1,600 \pm 200^{\mathrm{b}}$ & $2,100 \pm 100^{b}$ & $7,600 \pm 120^{\mathrm{a}}$ & $300 \pm 10^{\mathrm{a}}$ & $1.08 \pm 0.01^{\mathrm{a}}$ & $5.75 \pm 0.01^{\mathrm{b}}$ & $14.28 \pm 0.01^{\mathrm{b}}$ & $33.23 \pm 0.01^{\mathrm{b}}$ \\
\hline SSB $10 \%$ & $11,100 \pm 100^{\mathrm{b}}$ & $1,600 \pm 100^{\mathrm{b}}$ & $2,900 \pm 200^{\mathrm{c}}$ & $15,200 \pm 130^{\mathrm{b}}$ & $1,700 \pm 150^{\mathrm{b}}$ & $1.17 \pm 0.02^{\mathrm{ab}}$ & $6.25 \pm 0.02^{\mathrm{c}}$ & $14.78 \pm 0.01^{\mathrm{b}}$ & $35.61 \pm 0.02^{\mathrm{c}}$ \\
\hline SSB $15 \%$ & $11,600 \pm 100^{\mathrm{c}}$ & $1,800 \pm 100^{\mathrm{c}}$ & $2,900 \pm 100^{\mathrm{c}}$ & $14,800 \pm 150^{\mathrm{b}}$ & $1,900 \pm 110^{\mathrm{b}}$ & $1.37 \pm 0.01^{\mathrm{b}}$ & $7.38 \pm 0.01^{\mathrm{d}}$ & $16.06 \pm 0.02^{\mathrm{c}}$ & $37.24 \pm 0.02^{\mathrm{d}}$ \\
\hline SSB $20 \%$ & $11,600 \pm 200^{\mathrm{c}}$ & $1,800 \pm 100^{\mathrm{c}}$ & $2,900 \pm 200^{c}$ & $14,900 \pm 100^{\mathrm{b}}$ & $2,000 \pm 150^{\mathrm{b}}$ & $1.20 \pm 0.02^{\mathrm{ab}}$ & $7.86 \pm 0.01^{\mathrm{d}}$ & $16.49 \pm 0.02^{\mathrm{c}}$ & $39.05 \pm 0.01^{\mathrm{e}}$ \\
\hline
\end{tabular}

Values followed by different letters within columns indicate significant differences $(P \leq 0.05)$. Fisher's least significant differences (LSD) test was used to differentiate means with $95 \%$ confidence.

Table 5. Sensory evaluation of the snack bars added with marolo flour (SSB) in different concentrations.

\begin{tabular}{lccccc} 
Samples & Appearance & Aroma & Taste & Texture & $\begin{array}{c}\text { Overall } \\
\text { acceptance }\end{array}$ \\
\hline Control & $7.10^{\mathrm{a}}$ & $6.92^{\mathrm{a}}$ & $6.87^{\mathrm{a}}$ & $7.10^{\mathrm{a}}$ & $7.00^{\mathrm{b}}$ \\
SSB 5\% & $7.32^{\mathrm{b}}$ & $7.22^{\mathrm{ab}}$ & $7.04^{\mathrm{b}}$ & $7.35^{\mathrm{b}}$ & $7.27^{\mathrm{c}}$ \\
SSB 10\% & $7.26^{\mathrm{ab}}$ & $7.17^{\mathrm{ab}}$ & $7.01^{\mathrm{b}}$ & $7.27^{\mathrm{b}}$ & $7.25^{\mathrm{c}}$ \\
SSB 15\% & $7.28^{\mathrm{ab}}$ & $7.37^{\mathrm{b}}$ & $6.92^{\mathrm{ab}}$ & $7.34^{\mathrm{b}}$ & $7.11^{\mathrm{b}}$ \\
SSB 20\% & $7.15^{\mathrm{a}}$ & $7.36^{\mathrm{b}}$ & $6.75^{\mathrm{a}}$ & $7.31^{\mathrm{b}}$ & $6.50^{\mathrm{a}}$ \\
\hline
\end{tabular}

Values followed by different letters within columns indicate significant differences $(P \leq 0.05)$. Fisher's least significant differences (LSD) test was used to differentiate means with $95 \%$ confidence. 